INTERNATIONAL JOURNAL OF RESEARCHES IN BIOSCIENCES, AGRICULTURE AND TECHNOLOGY (C) VISHWASHANTI MULTIPURPOSE SOCIETY (Global Peace Multipurpose Society) R. No. MH-659/13(N) www.ijrbat.in

\title{
CASSIA UNIFLORA MILL.A NEW ENTRY IN THE REALM OF INVASIVE FLORA OF INDIA AND ITS EFFECT ON SOIL PROPERTIES
}

\author{
*Vaishali Ramgunde and Alka Chaturvedi \\ Department of Botany, Rashtrasant Tukadoji Maharaj Nagpur University, Nagpur, India \\ ${ }^{*}$ Corresponding author's email: vramgunde@gmail.com
}

\begin{abstract}
:
Invasion of Cassia uniflora Mill. in Central India covering all type of habitats is capable of causing changes in soil properties. We analyzed effect of this invader in sites like forest, wasteland and protected area with reference to soil properties. Results showed preference of C. uniflora to porous soil with $\mathrm{pH}$ ranging from 6.9 to 7.7 and higher EC than non-invaded soil. It can thrive well in wide range of soil organic carbon and nitrogen. Nutrients like phosphorus, potassium, calcium, magnesium, sodium and free $\mathrm{CaCO} 3$ were abundant in its soil. It can survive in a wide range of ecological requirements with varied habitat and can alter nutrient status of soil because of its presence but they may survive in any type of soil with poor nutrients. High AMF was determined in C. uniflora. Hyphae, vesicles and arbuscules were also seen in roots of this invader. Rhizosphere soil was observed with good spore population.
\end{abstract}

Keywords: Cassia uniflora, invasion, soil properties, nutrients.

\section{INTRODUCTION:}

Although Cassia uniflora is the new entry to the area under study but it is making its new territory more favorable for its sustenance by changing soil properties. Its dominance in the selected area showed that it affected soil chemistry in such a way that other plants are finding it difficult for their survival which in turn favoring the habitat for formers spread. Members of the family Caesalpiniaceae are characterized for the presence of root nodules for nitrogen fixation but Cassia uniflora was reported thriving very well without root nodule (Ramgunde, 2017). This observation made us to put question mark on role of root nodules. Moreover it might be the strategy of this invasive to spread at faster rate. Even though India is facing significant environmental and economic problems due to enormous growth and spread of invasive alien species, research on various aspects of invasive alien species is lagging somewhere and moreover geographical range of flora plays a crucial role in the process of invasion of the plant, hence there is an immediate need to investigate overlooked invasive alien species and their ecological status, spreading pace etc. On the basis of observations about its dominance we studied its effect on soil characteristics and soil microflora of area under study.

\section{METHOD AND MATERIAL:}

Plant species

Cassia uniflora is a native of Tropical South America (Reddy, 2008) belonging to family Caesalpiniaceae, was selected for the present study. Cassia uniflora Mill. Non Spreng. (hereafter it will be referred as $C$. uniflora) is the non native, annual, herbaceous weed, full sunlight or shade loving, it grows luxuriantly at places like forest, highways, railway tracks, and wasteland and even it is seen in agricultural fields.

Study area

Nagpur lies in the centre of India and zero milestone of India is situated within this city. It lies between $210 \mathrm{~N}$ latitude and $790 \mathrm{E}$ longitude. On the basis of field observation for all the seasons in one year (2011-2012), three different sites were selected for the present study. Satellite maps of the sites were downloaded from https://earthygoogle.com/web

University campus of Rashtrasant Tukadoji Maharaj Nagpur University, Nagpur was assigned as Site I (Fig 1). Site II was Katol bypass which is a open 
wasteland and road sides (Fig 2.1 and 2.2). Gorewada Biodiversity Park and some area of forest was site III (Fig 3).

Data collection and analysis

Soil samples were collected from invaded and noninvaded sites at a depth of $0 \mathrm{~cm}-15 \mathrm{~cm}$ using a spade. Five soil samples were collected from each invaded and non-invaded sites. These five samples were mixed and about $1 / 2 \mathrm{~kg}$ of soil was procured for soil analysis. Soil samples were air dried and were ground with a wooden pestle and mortar. After grinding, the soil was screened through a $2 \mathrm{~mm}$ sieve. Same procedure was repeated for consecutive 3 years and mean of three readings was calculated for each parameter. Methods for soil analysis were referred from Soil testing in India, Methods manual (2011).

Soil texture was estimated by using Hydrometer method. Moisture (\%) analysis was executed before any other analysis. Moisture \% was estimated by Gravimetric method. Maximum water holding capacity (MWHC), particle density, porosity (\%) and volume expansion (\%) were determined by using Keen-Raczkowski box method adopted from Viji and Prasanna (2012). The soil $\mathrm{pH}$ was estimated by using pH meter (Orion star A211). EC (mS/cm) was measured by using EC meter (Orion star A212). Organic carbon (\%) was estimated by Walkley and Black (1934) method. Available Nitrogen (N) in soil was estimated by Alkaline Permanganate method (Subbhaiah and Asija, 1956). Available Phosphorus (P) was determined by P-Olsen method (Olsen et al., 1954). Available Potassium (K) was estimated with the help of flame photometeric (Elico-CL378 Flame photometer) method (Toth and Prince, 1949). Exchangeable Calcium (Ca) and Magnesium (Mg) were analyzed by Versenate titration method. Exchangeable Sodium (Na) was analyzed by flame photometry method. Free Calcium carbonate (CaCO3 \%) was estimated by Piper method (Piper, 1966).
Isolation of fungal spore from rhizosphere soil of $\mathrm{C}$. uniflora was done by using wet sieving and decanting technique given by Gerdemann and Nicolson (1963). Percent mycorrhiza colonization in the roots of the plant was estimated using technique of Phillips and Hayman (1970).

Statistical Analysis

Data generated from present investigation was analyzed statistically by using SPSS version 17 (SPSS incorporation). One way ANOVA was applied at the $\mathrm{P}<0.05$ level. The resulted data was further analyzed by applying Post Hoc Test to find out significant difference between the means at the $\mathrm{P}<$ 0.05level. In one way ANOVA, some results were significant but Post Hoc test did not showed significant difference.

\section{RESULTS AND DISCUSSION}

From the results it was evident that C. uniflora preferred soil with clay and little silt but sand was less compared to non-invaded soil. Moisture \% and MWHC varied from $9.28 \%$ to $11.50 \%$ and 19.57 to 27.55 respectively. Particle and apparent density, and porosity \% was found to be more while volume expansion \% less in C. uniflora invaded soil compared to non-invaded soil. These varied range of invaded soil properties revealed adaptability of this plant. C. uniflora has showed luxuriant growth in between soil $\mathrm{pH} 6.8$ to 7.7. EC for C. uniflora invaded soil was recorded higher compared to noninvaded soil indicating C. uniflora soil solution with more amount of soluble salts which ranged from $0.36 \mathrm{mS} / \mathrm{cm}$ to $0.41 \mathrm{mS} / \mathrm{cm}$. Organic carbon and nitrogen in $C$. uniflora invaded soil varied from $0.32 \%$ to $0.61 \%$ and $223.33 \mathrm{~kg} / \mathrm{ha}$ to $434.33 \mathrm{~kg} / \mathrm{ha}$ respectively. It was delineated that $C$. uniflora invaded sites were having more soil phosphorus compared to non-invaded sites which varied from $13 \mathrm{~kg} /$ ha to $15 \mathrm{~kg} /$ ha. Mean value of potassium for C. uniflora invaded soil varied from $484.67 \mathrm{~kg} /$ ha to $1122.67 \mathrm{~kg} / \mathrm{ha}$ which was found to be quiet higher compared to non-invaded soil. C. uniflora invaded soil was found to be rich in nutrients compared to 
non-invaded soil, such as phosphorus, potassium, calcium, magnesium, sodium and free $\mathrm{CaCO}_{3}$ except for site III where $\mathrm{CaCO}_{3}$ reported to be lower.

C. uniflora had been observed to occupy a relatively broad $\mathrm{pH}$ range from acidic to alkaline. Under the exotic invasive Lepidium latifolium, decreased $\mathrm{pH}$ was also invoked as a possible mechanism for the increased phosphorus availability (Blank and Young, 2002). Present findings showed increase as well as decrease in $\mathrm{pH}$ in invaded soil and similar observations were noted by Ehrenfeld (2003). EC was found to be increased in invaded plots compared to non-invaded plots. Soil $\mathrm{pH}$ and electrical conductivity was more in invaded sites over the non-invaded sites (Upadhyay et al., 2013) which corroborate with present findings.

Soil nutrient pool was seemed to be variously affected by invasion. Invaded site II showed lower organic carbon and nitrogen value over non-invaded site. Invaded site I had less organic carbon and nitrogen whereas invaded site III with higher organic carbon and nitrogen had been observed. According to Vitousek et al., (1997) increased levels of soil nitrogen caused by atmospheric nitrogen deposition can increase the dominance of invasive alien plants and decrease the diversity of plant communities worldwide. Present finding delineated that organic carbon and nitrogen availability in invaded sites was varied and site and species specific. No significant changes were found on soil nitrogen and organic carbon by Parthenium invasion in grasslands of central Nepal (Timsina, 2007) while Chen et al., (2009) showed that Mikania micrantha significantly affected soil nutrients and nitrogen transformation in a study conducted in South China. Result revealed that no any clear relation was observed for organic carbon and \% nitrogen in soil under Noninvaded and Invaded sites (Upadhyay et al., 2011). Higher content of carbon and nitrogen in invaded site over non-invaded sites corroborate with findings of Bidwell et al., (2006); Sharma and Raghubanshi (2011).
The invaded sites had higher amount of phosphorus and potassium pool. Similar findings of higher NPK in invaded soil were reported by Duda et al., (2003), Sanon et al., (2009). In contrast, Dobhal et al., (2010) observed lower value for NPK, calcium and magnesium in Lantana camara invaded soil compared to non-invaded soil. Elevated phosphorus has been found consistently to be associated with exotic plant species success in various communities studied (Clements, 1983; King and Buckney, 2002; Lake and Leishman, 2004; Leishman et al., 2004). Calcium and magnesium (meq\%) in invaded sites was found maximum compared to non-invaded sites. Soil sodium and free $\mathrm{CaCO}_{3}$ seemed to be increased in invaded sites over non-invaded.

Most published studies report increased soil nutrient stock and/or availability under invasive plant species compared to uninvaded ecosystems (Musil, 1993; Scott et al., 2001; Duda et al. 2003; Vanderhoeven et al., 2005; Chapuis-Lardy et al., 2006; Liao et al., 2008), whereas other studies show the opposite pattern (Christian and Wilson, 1999; Leary et al., 2006). In addition, depending on local conditions, the same species may have different impacts (Stock et al., 1995; Meyerson et al., 2000; Belnap and Philips, 2001; Scott et al., 2001).

From Table 2 it's evident that $C$. uniflora roots were having hyphae with spore population 42.67 spore/25 g soil. Non native invasive species for their own proliferation may variously interact with soil biota and can change their growth and development strategy.

According to Brundret (2002) Arbuscular mycorrhizal fungi (AMF) form symbiotic associations with nearly $90 \%$ land plants and play important role in plant nutrient acquisition and species interactions. Presence of mycorrhizae allows the root to explore a greater volume of soil for nutrients, as the absorption surface increases several fold due to fungal hyphae. Nutrient transfer especially for phosphorus and absorption of nitrogen and other nutrients with low diffusion rates, is also facilitated 
by mycorrhizae (Singh et al., 2008). Reports of a few case studies showed positive impacts of the mycorrhizal symbiosis on the growth and development of alien plant species, resulting in a competitive advantage over native species (Fumanal et al., 2006; Sun and He, 2010; Chmura and Gucwa-Przepiora, 2012). Increasing abundance of some invasive plants species has been attributed to their ability to associate with AMF (Klironomos, 2002; Stampe and Daehler, 2003).

\section{CONCLUSION:}

C. uniflora preferred porous soil with $\mathrm{pH}$ ranging from 6.9 to 7.7 and higher EC than non-invaded soil. Wide range of soil organic carbon and nitrogen was seemed to be favorable for its luxuriant growth. Nutrients like phosphorus, potassium, calcium, magnesium, sodium and free $\mathrm{CaCO}_{3}$ were abundant in its soil. Interaction with AMF can change their growth and development strategy to proliferate at faster pace in their invaded range over native.

The present study had worked out on structural aspect of selected sites and observed invasion by $C$. uniflora. The process of invasion might be at initial stage, with other factors suitable for invasion in the selected sites; early management must be worked out before it affects the whole ecosystem and somewhere economy of the region which may be meager, but cannot be overlooked.

\section{ACKNOWLEDGMENTS :}

We are thankful to District Soil Survey and Soil Testing department and Professors of Department of Chemistry, Panjabrao Krishi Vidyapeeth, Nagpur, for their valuable guidance and assistance for soil analysis. We are also grateful to Dr. (Mrs.) Rekha Sharma, UGC, Academic Staff College, Rashtrasant Tukadoji Maharaj Nagpur University, Nagpur for providing me help in statistical analysis of results of this research work.

\section{REFERANCE :}

Belnap, J., and Philips, S. L. (2001): Soil biota in an ungrazed grassland: response to annual grass (Bromustectorum) invasion. Ecol. Appl. 11, Pp.1261-1275.

Bidwell, S., Attiwill, P. M., and Adams, M. A. (2006): Nitrogen availability and weed invasion in a remnant native woodland in urban Melbourne. Australian Ecology.31, Pp.262-270.

Blank, R. R., and Young, J. A. (2002): Influence of the exotic invasive crucifer, Lepidiumlatifolium, on soil properties and elemental cycling. Soil Sci. 167, Pp.821-829.

Brundrett, M. C. (2002): Co-evoluntion of roots and mycorrhizas of land plants. New Phytol, 154, Pp.275-304.

Chapuis-Lardy, L., Vanderhoeven, S., Dassonville, N., Koutika, L.S., and Meerts, P. (2006): Effect of the exotic invasive plant Solidagogigantea on soil phosphorus status. Biology \& Fertility of Soils, 42, Pp.481-489.

Chen, B. M., Peng, S. L., and Ni, G. Y. (2009): Effects of the invasive plant Mikaniamicrantha on soil nitrogen availability through allelopathy in South China. Biological Invasions, 11(6), Pp. 1291-1299.

Chmura, D., and Gucwa-Przepiora, E. (2012): Interactions between arbuscularmycorrhiza and the growth of the invasive alien annual Impatiens parviflora DC: a study of forest type and soil properties in nature reserves (S Poland). Applied Soil Ecology, 62, Pp.71-80.

Christian, J. M., and Wilson, S. D. (1999): Longterm ecosystem impacts of an introduced grass in the northern Great Plains. Ecology, 80, Pp.2397-2407.

Clements, A. (1983): Suburban development and resultant changes in the vegetation of the bushland of the northern Sydney region. Aust. J. Ecol, 8,Pp.307-19.

Dobhal, P., Kohli, R., and Batish, D. (2010): Evaluation of the impact of Lantana camara L. 
invasion, on four major woody shrubs, along Nayar river of PauriGarhwal, in Uttarakhand Himalaya. International Journal of Biodiversity and Conservation, 2(7), Pp.155-161. Available online

http://www.academicjournals.org/ijbc

Duda, J. J., Freeman, D. C., Emlen, J. M., Belnap, J., Kitchen, S.G., Zak, J. C., Sobek, E., Tracy, M., and Montante, J. (2003): Differences in native soil ecology associated with invasion of the exotic annual chenopod, Halogetonglomeratus. Biol. Fertil.Soils, 38, Pp.72-77.

Ehrenfeld, J. G. (2003): Mini review- Effects of of exotic plant invasions on soil nutrient cycling processes. Ecosystems, 6: Pp.503-523.

Fumanal, B., Plenchette, C., Chauvel, B., and Bretagnolle, F. (2006): Which role can arbuscular mycorrhizal fungi play in the facilitation of Ambrosia artemisiifolia $L$. invasion in France? Mycorrhiza, 17, Pp.25-35.

Gerdemann, J.W., and Nicolson, T.H. (1963): Spores of mycorrhizal Endogone species extracted from soil by wet sieving and decanting. Trans. Br. Mycol. Soc. 46, Pp.235-244.

King, S. A., and Buckney, R. T. G. (2002): Invasion of exotic plants in nutirent-enriched urban bushland. Austral Ecol. 27, Pp.573-83.

Klironomos, J. N. (2002): Feedback with soil biota contributes to plant rarity and invasiveness in communities. Nature, 417, Pp.67-70.

Lake, J. C., and Leishman, M. R.(2004): Invasion success of exotic plants in natural ecosystems: the role of disturbance, plant attributes and freedom from herbivores. Biological Conservation 117, Pp.215-226. Available online at www.sciencedirect.com

Leary, J. K., Hue, N. V., Singleton, P. W., and Borthakur, D. (2006): The major features of an infestation by the invasive weed legume gorse (Ulexeuropaeus) on volcanic soils in Hawaii. BiolFertil Soils, 42, Pp.215-223.
Leishman M. R., Hughes M. T., and Gore D. B. (2004): Soil phosphorus enhancement below storm water outlets in urban bushland: spatial and temporal changes and the relationship with invasive plants. Aust. J. Soil Res,.42,Pp.197-202.

Liao, C., Peng, R., Luo, Y., Zhou, X., Wu, X., Fang, C., Chen, J., and Li, B. (2008): Altered ecosystem carbon and nitrogen cycles by plant invasion: a meta-analysis. New Phytol, 177, Pp.706-714.

Meyerson, L. A., Saltonstall, K., Windham, L., Kiviat, E., and Findlay, S. (2000): A comparison of Phragmites australis in freshwater and brackish marsh environments in North America. Wetland Ecol. Manage., 9, Pp.89-103.

Musil, C.F. (1993): Effect of invasive Australian acacias on the regeneration, growth and nutrient chemistry of South African lowland fynbos. Journal of Applied Ecology, 30, Pp.361-372.

Olsen, S.R., Cole, C.V., Watanabe, F. S., and Dean, L.A. (1954): Estimation of available phosphorus in soils by extraction with sodium bicarbonate. CireUSQep.Agri. Q 39.

Philips, J. M., and Hayman, D. S. (1970): Improved procedures for clearing roots and staining parasitic and vesicular-arbuscular mycorrhizal fungi for rapid assessment of infection. Trans. Br. Mycol. Soc., 55, Pp.158-161.

Ramgunde V.R. (2017):Study on ecology and biology of some invasive plants from Central India, Thesis submitted to Rashtrasant Tukadoji Maharaj Nagpur University, Nagpur, for the degree of Doctor of Philosophy.

Piper, C. S. (1966): Soil and plant analysis. Hans publications, Bombay.

Reddy, C. (2008): Catalogue of invasive alien flora of India. Life Science Journal, 5(2), Pp.84-89.

Sanon, A., Beguiristain, T., Cébron, A., Berthelin, J., Ndoye, I.,Leyval, C., Sylla, S., and 
Duponnois, R. (2009): Changes in soil diversity and global activities following invasions of the exotic invasive plant, Amaranthusviridis L., decrease the growth of native sahelian Acacia species. FEMS Microbiol.Ecol. 70, Pp.118-131.

Scott, N., Saggar, S., and McIntosh, P. (2001): Biogeochemical impact of Hieracium invasion in New Zealand's grazed tussock grasslands: sustainability implications. Ecol Appl., 11, Pp.1311-1322.

Sharma, G.P., and Raghubanshi, A.S. (2011): Lantana camara L. Invasion and impact on herb layer diversity and soil properties in a dry deciduous forest of india. Applied Ecology and Environmental Research, 9(3), Pp.253-264.

Singh, J. S., Singh, S. P., and Gupta, S. R. (2008): Ecology Environment and Resource Conservation. Anamaya publishers.

Soil testing in India, Methods Manual. (2011): Department of Agriculture and Cooperation, Ministry of Agriculture, Government of India, New Delhi.

Stampe, E. D., and Daehler, C. C. (2003): Mycorrhizal species identity affects plant community structure and invasion: a microcosm study. Oikos, 100, Pp.362-372.

Stock, W. D., Wienand, K. T., and Baker, A. C. (1995): Impacts of invading N2-fixing Acacia species on patterns of nutrient cycling in two Cape ecosystems: evidence from soil incubation studies and $15 \mathrm{~N}$ natural abundance values. Oecologia, 101, Pp.375382 .

Subbaiah, B.V., and Asija, G. L. (1956): A Rapid Procedure for the Estimation of Available Nitrogen in soils. Curr.Sci., 25, Pp.259 - 260.

Sun Z.K., and He W.M. (2010): Evidence for Enhanced Mutualism Hypothesis: Solidagocanadensis plants from regular soils perform better. PLoSONE 5(11): e15418. doi:10.1371/journal.pone.0015418. Pp.1-5.
Timsina, B. (2007): Impact of Partheniumhysterophorus L. Invasion on Soil and Plant species composition of Grasslands of Central Nepal. [M. Sc. Dissertation] Central Department of Botany, Tribhuvan University, Kathmandu, Nepal. 61.

Toth, S. J., and Prince A. L. (1949): Estimation of cation exchange capacity and exchangeable calcium, potassium, and sodium contents of soils by flame photometer techniques, Soil Science, 67, Pp.439-445.

Upadhyay, S. K., Ahmad, M., and Singh, A. (2013): Ecological impacts of weed (Partheniumhysterophorus L.) invasion in saline soil. International Journal of Scientific and Research Publications, 3 (4), Pp.1-4. Available online at www.ijsrp.org

Upadhyay, S. K., Singh, J. S., and Singh, D. P. (2011): Exopolysaccharide-producing plant growth-promoting rhizobacteria under salinity condition. Pedosphere, 21, Pp.214-222.

Vanderhoeven, S., Dassonville, N., and Meerts, P. (2005): Increased topsoil mineral nutrient concentrations under exotic invasive plants in Belgium. Plant Soil, 275, Pp.167-177.

Viji, R., and Prasanna, P. R. (2012): Assessment of Water holding capacity of major soil series of lalgudi, Trichy ,India.J. Environ. Res. Develop., 7 (1A), Pp.393-398.

Vitousek, P. M., Aber, J., Howarth, R.W., Likens, G.E., Matson, P.A., Schindlere, D.W., Schlesinger, W.H., and Tilman, G.D. (1997): Human alteration of the global nitrogen cycle: causes and consequences. Issues in Ecology, 1, Pp.1-15.

Walkely, A.J., and Black, I.A. (1934): Estimation of soil organic carbon by the chromic acid titration method. Soil sci., 37, Pp.29-38.Table 1: Concentrations of Samples for HPTLC 


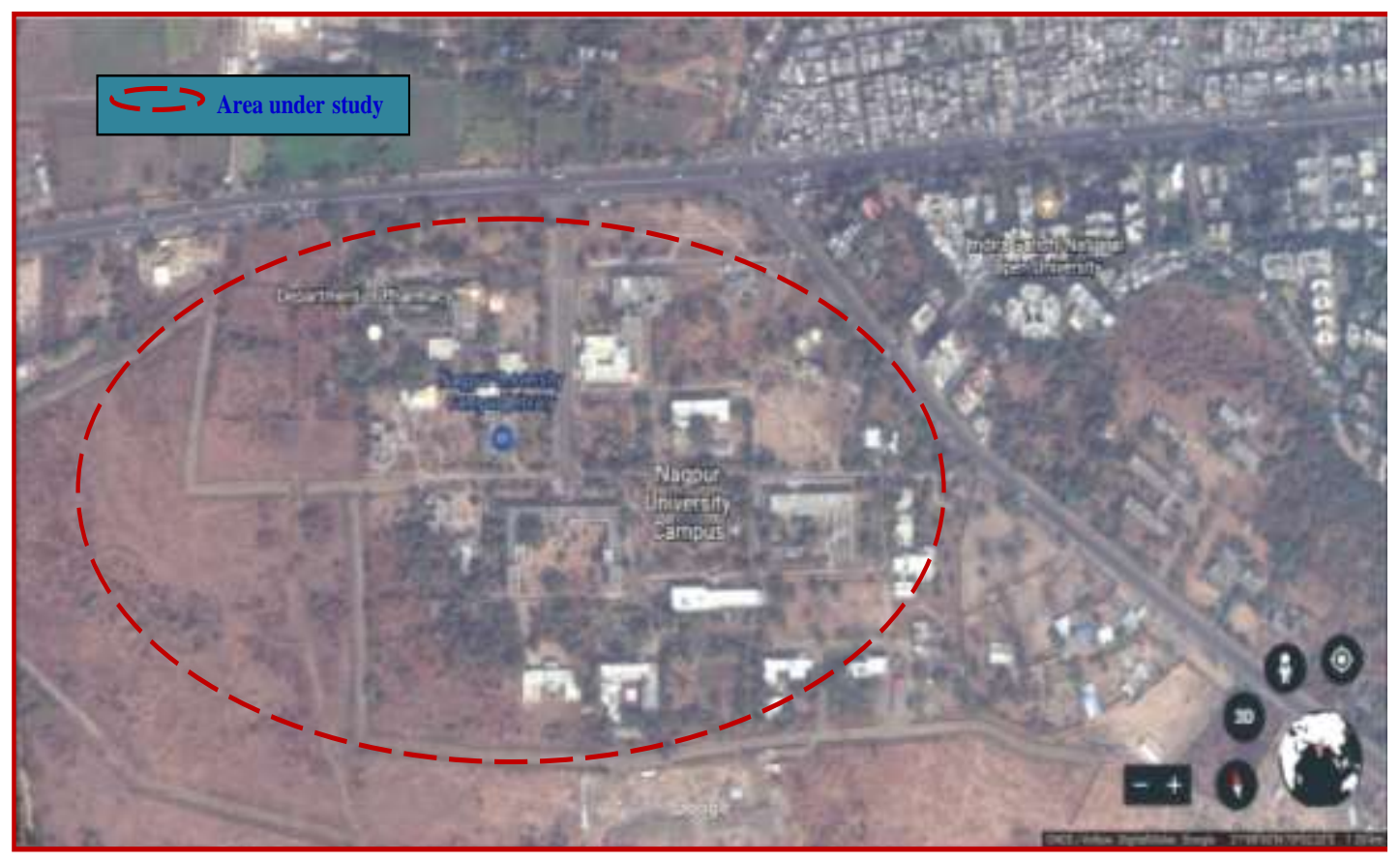

Fig1: Location of Site I - Rashtrasant Tukadoji Maharaj Nagpur University Campus, Nagpur

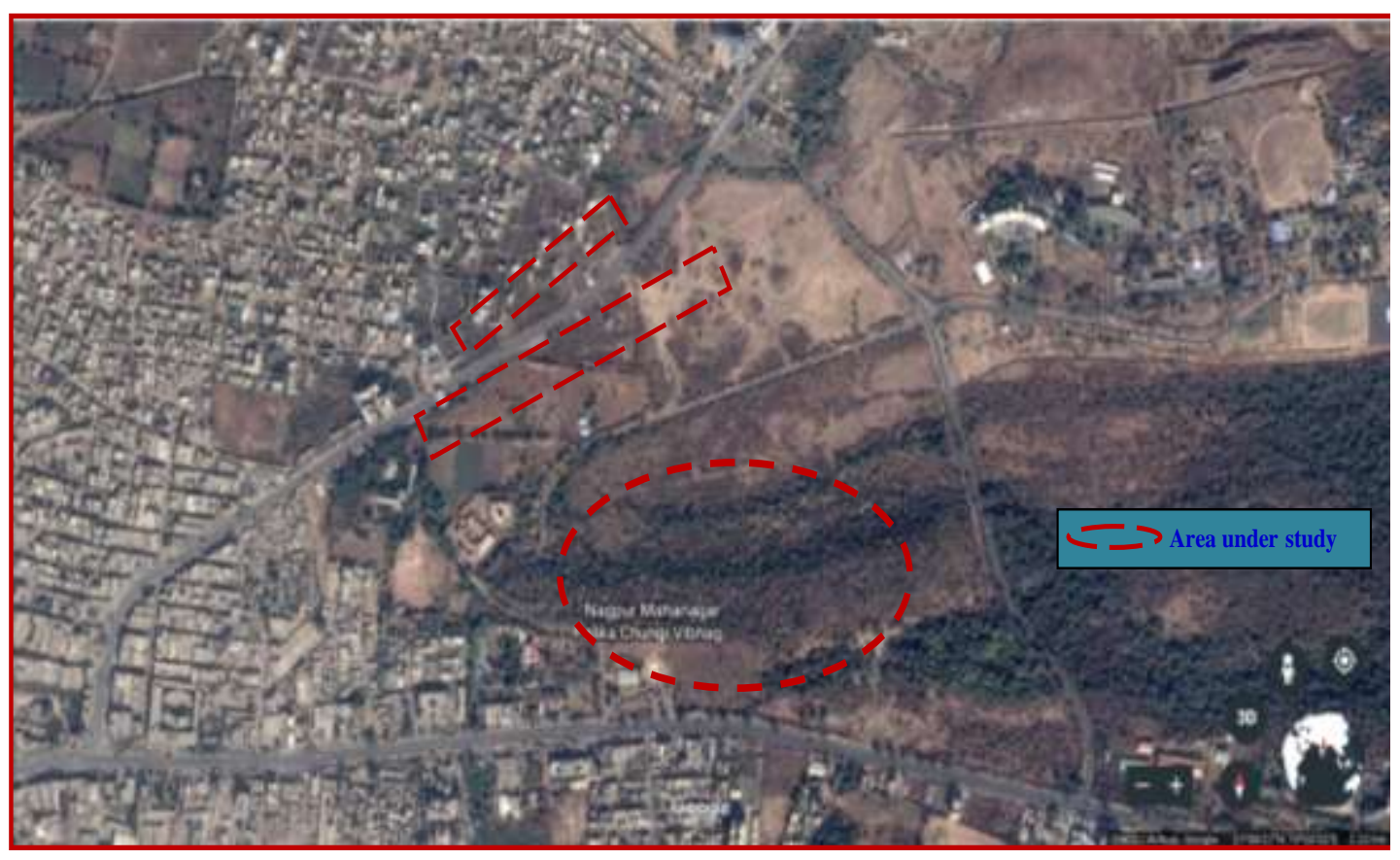

Fig 2.1:Location of Site II - Katol Bypass (a) (Dabha bypass) 


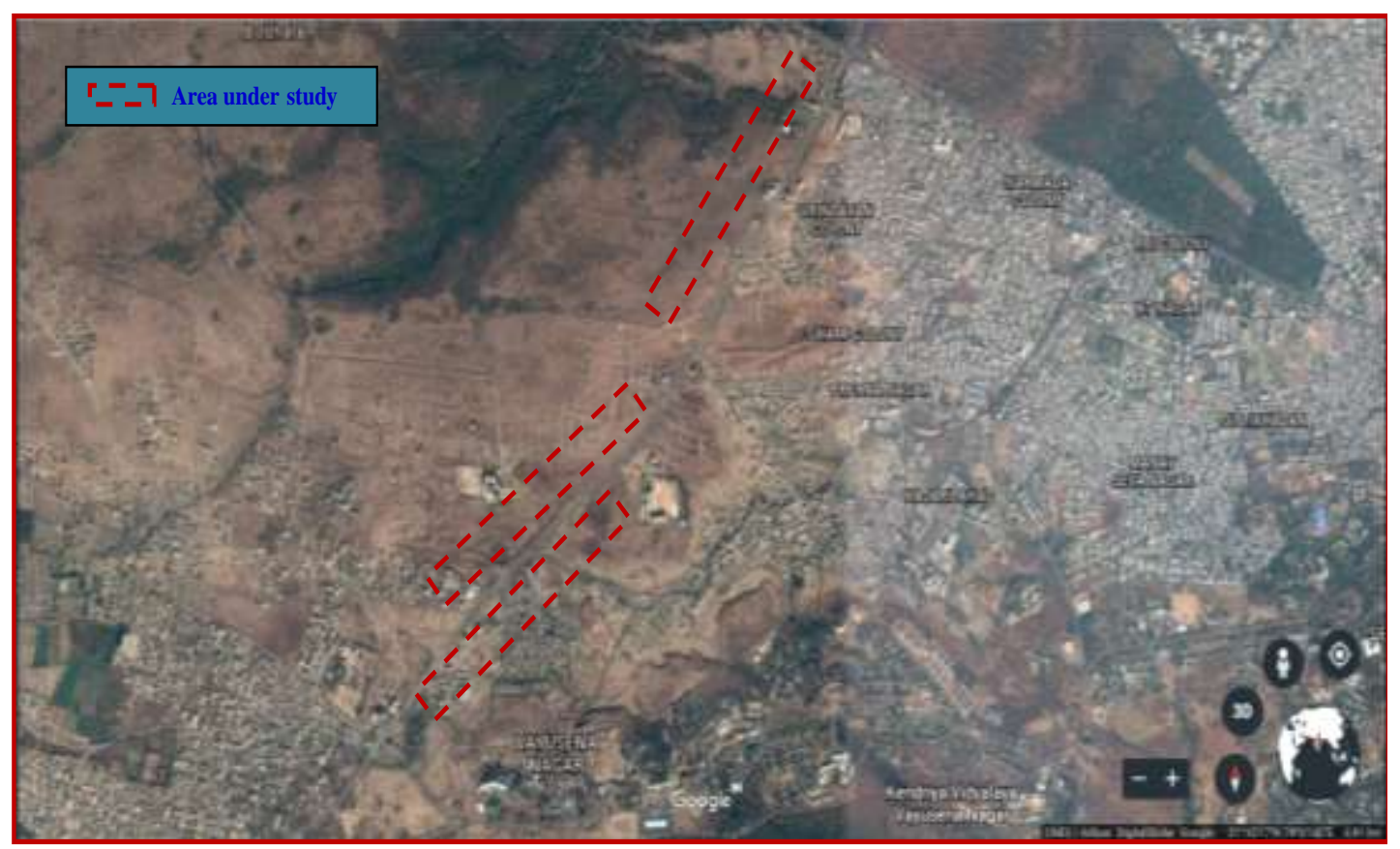

Fig 2.2:Location of Site II- Katol Bypass (b) (Dabha Road)

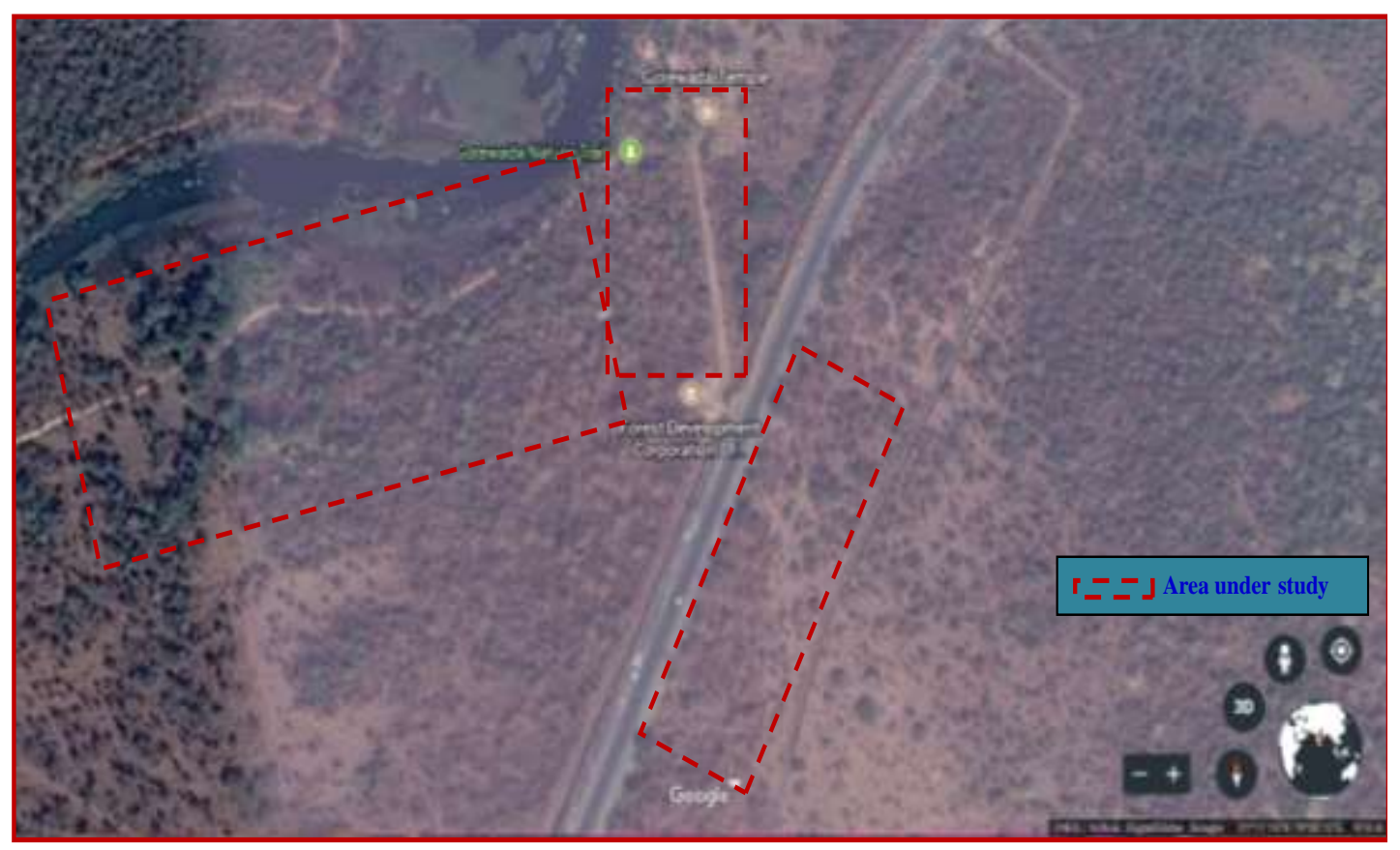

Fig 3: Location of Site III - Gorewada Biodiversity Park and some area of Gorewada Forest 
Table 1: Physical-chemical properties of non-invaded and invaded soil by Cassia uniflora from selected

\begin{tabular}{|c|c|c|c|c|c|c|c|c|}
\hline Properties & $\begin{array}{l}\text { Site I Non- } \\
\text { invaded } \\
\text { (MEAN } \pm \mathrm{SE})\end{array}$ & $\begin{array}{l}\text { Site I Invaded } \\
(\mathrm{MEAN} \pm \mathrm{SE})\end{array}$ & $\begin{array}{l}\text { Site II Non- } \\
\text { invaded } \\
\text { (MEAN } \pm \mathrm{SE})\end{array}$ & $\begin{array}{l}\text { Site II Invaded } \\
\text { (MEAN } \pm \text { SE) }\end{array}$ & $\begin{array}{l}\text { Site III Non- } \\
\text { invaded } \\
(\mathrm{MEAN} \pm \mathrm{SE})\end{array}$ & $\begin{array}{l}\text { Site III Invaded } \\
\qquad(\mathrm{MEAN} \pm \mathrm{SE})\end{array}$ & F- value & $\mathrm{P}$-value \\
\hline Sand (\%) & $33 \pm 1.155^{\mathrm{abcd}}$ & $13.67 \pm 1.202^{\mathrm{afg}}$ & $18 \pm 2.082^{\mathrm{b}}$ & $25 \pm 1.528^{\mathrm{fh}}$ & $24.33 \pm 1.202^{\mathrm{ceg}}$ & $14.33 \pm 1.453^{\mathrm{deh}}$ & 25.60 & 0.000 \\
\hline Silt (\%) & $13.33 \pm 2.028^{\mathrm{abcd}}$ & $23.67 \pm 1.453^{a}$ & $23.67 \pm 1.453^{\mathrm{b}}$ & $19.33 \pm 1.453$ & $24.33 \pm 1.764^{c}$ & $24 \pm 1.155^{d}$ & 7.65 & 0.002 \\
\hline Clay (\%) & $54.33 \pm 2.028$ & $62.33 \pm 0.333$ & $62 \pm 5.774$ & $50.33 \pm 2.603$ & $47.67 \pm 1.453$ & $60.67 \pm 1.764$ & 4.89 & 0.011 \\
\hline Moisture (\%) & $9.98 \pm 0.015$ & $9.28 \pm 0.087 \mathrm{ab}$ & $9.25 \pm 0.147 \mathrm{~cd}$ & $11.35 \pm 0.728$ ace & $8.95 \pm 0.097$ ef & $11.50 \pm 0.283^{\mathrm{bdf}}$ & 11.47 & 0.000 \\
\hline MWHC & $34.42 \pm 0.444$ abcde & $27.55 \pm 0.308^{\text {afgh }}$ & $48.13 \pm 0.069^{b h i j k}$ & $19.57 \pm 0.252^{\text {cfil }}$ & $27.51 \pm 0.246 \mathrm{djlm}$ & $19.59 \pm 0.089 \mathrm{egkm}$ & 1608.57 & 0.000 \\
\hline $\begin{array}{c}\text { Particle } \\
\text { density }(g m / c c)\end{array}$ & $1.18 \pm 0.017$ abcde & $2.07 \pm 0.027$ afj & $1.55 \pm 0.014$ bfghik & $2.14 \pm 0.017 \mathrm{cg}$ & $1.02 \pm 0.015^{\mathrm{dhjkl}}$ & $2.04 \pm 0.020$ eil & 646.38 & 0.000 \\
\hline Porosity (\%) & $44.79 \pm 0.106^{\text {abcde }}$ & $68.01 \pm 0.504$ afghi & $48.25 \pm 0.326^{\mathrm{bfjkl}}$ & $58.71 \pm 0.145^{\text {cgjmn }}$ & $27.45 \pm 1.252 \mathrm{dhkmo}$ & $63.39 \pm 0.361$ eilno & 630.78 & 0.000 \\
\hline $\begin{array}{c}\text { Volume } \\
\text { expansion(\%) }\end{array}$ & $28.66 \pm 0.611^{\mathrm{abc}}$ & $7.06 \pm 0.092^{\text {ade }}$ & $28.66 \pm 0.610^{\mathrm{dfg}}$ & $8.66 \pm 0.116^{\mathrm{bfh}}$ & $27.64 \pm 0.053^{\mathrm{ehi}}$ & $8.41 \pm 0.120^{\mathrm{cgi}}$ & 944.79 & 0.000 \\
\hline $\mathrm{pH}$ & $7.2 \pm 0.088$ & $6.8 \pm 0.202^{\mathrm{abc}}$ & $7.7 \pm 0.033 \mathrm{ad}$ & $7.7 \pm 0.088$ be & $7.6 \pm 0.088 \mathrm{cf}$ & $6.9 \pm 0.088 \mathrm{def}$ & 13.30 & 0.000 \\
\hline $\mathrm{EC}(\mathrm{mS} / \mathrm{cm})$ & $0.23 \pm 0.033^{\mathrm{ab}}$ & $0.39 \pm 0.023^{\mathrm{acd}}$ & $0.13 \pm 0.033^{\mathrm{cef}}$ & $0.41 \pm 0.020^{\text {beg }}$ & $0.18 \pm 0.014 \mathrm{dgh}$ & $0.36 \pm 0.010^{\mathrm{fh}}$ & 24.14 & 0.000 \\
\hline $\begin{array}{c}\text { Organic } \\
\text { carbon (\%) }\end{array}$ & $0.55 \pm 0.029 \mathrm{ab}$ & $0.32 \pm 0.003^{\text {acde }}$ & $0.65 \pm 0.017^{\mathrm{cf}}$ & $0.55 \pm 0.012^{\mathrm{dg}}$ & $0.36 \pm 0.026^{\mathrm{bfgh}}$ & $0.61 \pm 0.003^{\mathrm{eh}}$ & 54.81 & 0.000 \\
\hline $\begin{array}{l}\text { Nitrogen } \\
\text { (kg/ha) }\end{array}$ & $387.67 \pm 1.764 \mathrm{abcd}$ & $223.33 \pm 2.333^{\text {aefgh }}$ & $463.33 \pm 1.856^{\text {beij }}$ & $371.67 \pm 4.055^{\text {fikl }}$ & $258.67 \pm 5.487 \mathrm{cgkm}$ & $434.33 \pm 2.028^{\mathrm{dhjlm}}$ & 880.42 & 0.000 \\
\hline $\begin{array}{l}\text { Phosphorous } \\
\text { (kg/ha) }\end{array}$ & $13.33 \pm 1.453^{\mathrm{a}}$ & $14 \pm 1.732^{\mathrm{b}}$ & $4.33 \pm 0.333^{\mathrm{abcde}}$ & $13 \pm 1.155^{\mathrm{c}}$ & $13 \pm 1.155^{\mathrm{d}}$ & $15 \pm 2.309 \mathrm{e}$ & 6.85 & 0.003 \\
\hline $\begin{array}{l}\text { Potassium } \\
\text { (kg/ha) }\end{array}$ & $215.33 \pm 2.028$ abcde & $484.67 \pm 5.487^{\text {afghi }}$ & $94.33 \pm 2.028^{\mathrm{bj} k \mathrm{l}}$ & $1122.67 \pm 4.631^{\mathrm{cgimn}}$ & $131.33 \pm 3.756^{\mathrm{dhkmo}}$ & $693.67 \pm 10.171^{\text {eilno }}$ & 5385.63 & 0.000 \\
\hline $\begin{array}{l}\text { Calcium } \\
(\mathrm{meq} \%)\end{array}$ & $16.66 \pm 0.066^{\mathrm{abc}}$ & $36.33 \pm 0.881$ ade & $14.73 \pm 0.133^{\mathrm{dfg}}$ & $32.13 \pm 0.592^{\mathrm{bfh}}$ & $15.76 \pm 0.486^{\mathrm{ehi}}$ & $30.07 \pm 2.990^{\mathrm{cgi}}$ & 53.66 & 0.000 \\
\hline $\begin{array}{l}\text { Magnesium } \\
\text { (meq\%) }\end{array}$ & $11.44 \pm 1.009^{\mathrm{ab}}$ & $21.32 \pm 0.338^{\text {acdef }}$ & $11.69 \pm 0.245^{\mathrm{cg}}$ & $14.59 \pm 0.797^{\mathrm{dh}}$ & $5.97 \pm 0.577^{\text {beghi }}$ & $14.91 \pm 0.725^{\mathrm{fi}}$ & 57.24 & 0.000 \\
\hline $\begin{array}{l}\text { Sodium } \\
\text { (meq\%) }\end{array}$ & $0.22 \pm 0.017$ & $0.57 \pm 0.237$ & $0.22 \pm 0.005$ & $0.52 \pm 0.008$ & $0.37 \pm 0.023$ & $0.40 \pm 0.000$ & 2.27 & 0.113 \\
\hline $\begin{array}{c}\text { Free } \mathrm{CaCO} 3 \\
(\%)\end{array}$ & $7.08 \pm 0.506 \mathrm{abc}$ & $8.53 \pm 0.359 \mathrm{defg}$ & $5.13 \pm 0.185^{\mathrm{adh}}$ & $5.56 \pm 0.296 \mathrm{ei}$ & $5.16 \pm 0.166^{b f j}$ & $1.95 \pm 0.040$ cghij & 54.71 & 0.000 \\
\hline
\end{tabular}

Data are the pooled means of three replicates \pm SE. Values with same letters are significantly different from each other according to Post Hoc test at the $\mathbf{p}<0.05$ level.

Table 2: Association of Arbuscular Mycorrhizal (AM) Fungi with C. uniflora

\begin{tabular}{|c|c|c|c|c|c|}
\hline Invasive species & Hyphae & Vesicles & Arbuscules & AM colonization (\%) & $\begin{array}{c}\text { Spore population per 25 g } \\
\text { soil (MEAN } \pm \text { SE) }\end{array}$ \\
\hline C. uniflora & + & - & - & 54 & $42.67 \pm 2.44$ \\
\hline
\end{tabular}

